\title{
Superfund Basic Research Program
}

National Cancer Institute

\section{Source}

National Cancer Institute. Superfund Basic Research Program. NCI Thesaurus. Code C82633.

A program of the National Institute of Environmental Health Sciences to create a network of university grants that are designed to seek solutions to the complex health and environmental issues associated with the nations hazardous waste sites. 